\title{
Billateral sudden deafness
}

\section{Therezita M. Peixoto Patury Galvão Castro ${ }^{1}$, Laurisson Albuquerque da Costa ${ }^{2}$, Maria Eliza Alencar Nemezio ${ }^{3}$, Lucas José Sá da Fonseca ${ }^{4}$}

Keywords: hearing loss, neurilemmoma, stroke, sudden.

\section{INTRODUCTION}

Sudden hearing loss is described as a sensorineural hearing loss starting at 30 decibels $(\mathrm{dB})$ in three of more contiguous frequencies, which can be severe and irreversible, which onset happens suddenly along 3 days. Auditory involvement is usually unilateral in 98\%-99\% of the cases ${ }^{1,2}$. It does not have a well-defined etiological factor, and most are idiopathic; it can be due to vascular involvement, viral infection, autoimmune disorder or rupture of the intracochlear membrane; etiology confirmation is rather difficult, since many can be the causal agents. Moreover, these factors may manifest in a synergic way, giving the disorder a multifactorial etiology ${ }^{3,4}$. The acoustic neuroma is considered a definitive cause of sudden hearing loss. The most frequent accompanying symptoms are tinnitus in $70 \%$ to $90 \%$ of the cases and dizziness in $20 \%$ to $40 \%$ of the cases ${ }^{4,5}$.

For the sudden hearing loss diagnosis, besides the detailed anamneses and physical exam, a complete audiometric evaluation is paramount, brainstem evoked-response audiometry (BERA), vestibular tests and trigeminal nerve assessment, as well as MRI with gadolinium and other tests in the pursue of the etiology $y^{5,6}$.

\section{CASE PRESENTATION}

M.T.T.A., female, an 82 yearold retiree, coming from Maceió - AL, was seen in the ENT ward, where she complained of tinnitus and sudden hearing loss in her right ear for about 12 years, at the time she was diagnosed with acoustic neuroma by means of an MRI (Figure 1). she also stressed that at about 18 months ago, after an emotional stress, she was affected by a sudden hearing loss episode in her left ear, when a skull CT scan was ordered for her, which showed a small hypodense area next to the right lateral ventricle horn (Figure 1), suggesting cerebral ischemic injury as the cause of the left-side sudden hearing loss. Audiology tests were carried out and upon tonal audiometry (Figure 1) we found a bilateral sensorineural hearing loss, and the patient still had a better hearing in her right ear. She was advised to wear a hearing aid in both ears and go through multidisciplinary outpatient follow up by a geriatrician, cardiologist and a neurologist.

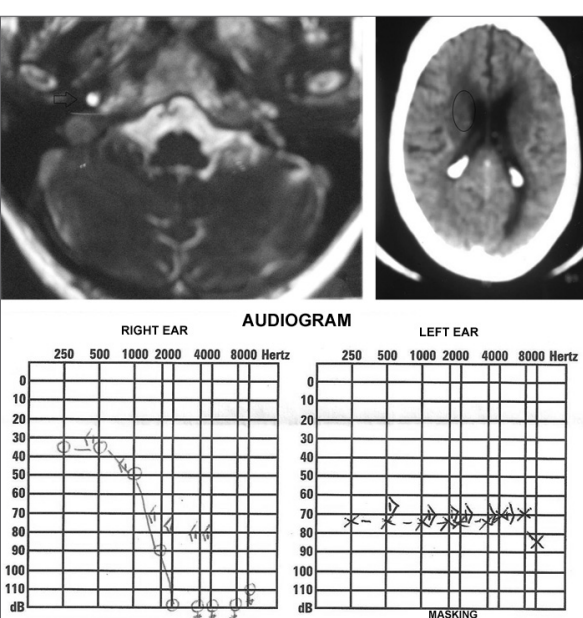

Figure 1. Complementary tests. Upper left-hand image: MRI showing an acoustic neuroma to the right (arrow); upper righthand image: skull CT showing a hypodense area near the right ventricle horn (circle); lower image: tonal audiometry showing hearing loss after a sudden hearing loss spell.

\section{DISCUSSION}

The case hereby reported is rare, it is a bilateral sudden hearing loss, of non-simultaneous occurrence, suggested by the tonal audiometry test $^{6}$, as it shows bilateral sensorineural hearing loss above $30 \mathrm{~dB}$ in more than three contiguous frequencies ${ }^{1,2}$ Initially, she had right ear hearing loss together with tinnitus - a common symptom in $80 \%$ of the cases ${ }^{4,5}$, and the hearing loss cause was established by the MRI, which showed an acoustic neuroma. Later, she had sudden hearing loss on the left side, of probable vascular involvement, which showed in the skull CT $\operatorname{scan}^{3,4}$.

\section{FINAL REMARKS}

The present report points to the likelihood of non-simultaneous sudden bilateral hearing loss, due to the participation of numerous etiological factors which, added together, may cause severe loss to the bearer. Thus, we stress the importance of the early diagnosis of hearing involvement and the control of pathologies, especially vascular ones, which may cause sudden hearing loss, as in this clinical case and thus have a negative repercussion in the quality of life of the elderly.

\section{REFERENCES}

1. Wilson WR, Byl FM, Laird N. The efficacy of steroids in the treatment of idiopathic sudden hearing loss. A double-blind clinical study. Arch Otolaryngol. 1980;106(12):772-6.

2. Vasama JP, Linthicum FH Jr. Idiopathic sudden sensorioneural hearing loss: temporal bone histopathologic study. Ann Otol Rhinol Laryngol. 2000;109(6):527-32.

3. Guyot JP, Thielen K. Evolution of sudden deafness without treatment. Schweiz Med Wochenschr Suppl. 2000;116:93S-96S.

4. Maia RA, Cahali S. Surdez súbita. Rev Bras Otorrinolaringol. 2004;70(2):238-48

5. Hashisaki GT. Perda auditiva Sensorial Súbita. In: Bailey B \& Johnson. Otorrinolaringologia Cirurgia de Cabeça e Pescoço. $4^{\underline{a}}$ edição: Rio de Janeiro. Ed. Revinter; 2010.p.1143-9.

6. Fitzgerald DC, Mark AS. Sudden hearing loss: frequency of abnormal findings on contrast-enhanced MR studies. AJNR Am J Neuroradiol.1998;19(8):1433-6.

${ }^{1} \mathrm{PhD}$ in Medicine - School of Medical Sciences of the Santa Casa de São Paulo (FCMSCSP). Adjunct Professor of Otorhinolaryngology - UNCISAL and UFAL. ${ }^{2}$ 6th year medical student - Federal University of Alagoas.

${ }^{3} 6$ th year medical student - Federal University of Alagoas.

${ }^{4} 6$ th year medical student - Federal University of Alagoas. Universidade Federal de Alagoas (UFAL).

Send correspondence to: Av. Álvaro Otacílio, 3031 apto. 402. Ponta Verde, Maceió - AL. CEP: 57035-180.

Paper submitted to the BJORL-SGP (Publishing Management System - Brazilian Journal of Otorhinolaryngology) on August 08, 2010; and accepted on October 12, 2010. cod. 7261 